\title{
O015. Evaluation of the genetic polymorphism of the $\alpha 3$ (CHRNA3) and $\alpha 5$ (CHRNA5) nicotinic receptor subunits, in patients with cluster headache
}

\author{
Maria Michela Cainazzo ${ }^{*}$, Ilaria Tiraferri ${ }^{1}$, Michela Ciccarese ${ }^{1}$, Angela Martinelli ${ }^{2}$, Cinzia Cameli ${ }^{2}$, Elena Bacchelli ${ }^{2}$, \\ Michele Zoli ${ }^{3}$, Luigi Alberto Pini ${ }^{1}$
}

From Abstracts from the 1st Joint ANIRCEF-SISC Congress

Rome, Italy. 29-31 October 2015

\section{Introduction}

About $80 \%$ of patients with cluster headache $(\mathrm{CH})$ have a history of cigarette smoking [1]; a common genetic basis between $\mathrm{CH}$ and smoking has been suggested by the identification of a gene cluster on chromosome $15 q 25$, encoding for neuronal acetylcholine receptor subunits $\alpha 3, \alpha 5$ and $\beta 4$ (CHRNA5-CHRNA3-CHRNB4). Receptors containing the $\alpha 5$ subunit contribute to nicotine withdrawal symptoms and anxiety modulation [2,3].

\begin{abstract}
Aim
To identify rare variants with a possible role in the etiology of $\mathrm{CH}$ and nicotine addiction, we investigated the genetic variants into the locus CHRNA5-CHRNA3 using the blood of $\mathrm{CH}$ patients and compared it with the blood of control patients (case-control association study).
\end{abstract}

\section{Materials and methods}

We enrolled 65 patients with $\mathrm{CH}$, of which 53 men and 12 women; male to female ratio $=4.4: 1$. In the sample there were 48 active smokers, 12 former smokers and 5 patients whom had never smoked. $\mathrm{CH}$ patients were, respectively, divided into two groups: 54 with episodic and 11 with chronic form. We analyzed three single nucleotide polymorphisms (SNPs) known to be associated with nicotine addiction (rs16969968 and rs6495306 localized on CHRNA5 gene; rs578776 localized on CHRNA3 gene) in $\mathrm{CH}$ patients and in a control group consisting of

\footnotetext{
* Correspondence: cainazzo.michela@policlinico.mo.it

${ }^{1}$ Headache and Drug Abuse Inter-Department Research Centre, University of Modena and Reggio Emilia, Modena, Italy

Full list of author information is available at the end of the article
}

263 individuals that were comparable for age, smoking status and geographic origin. The analysis of rare variants of the genes was performed by sequencing of the coding portion of the gene and 5'-untranslated region (5'UTR) with the Sanger method. The sequence and genomic organization were obtained from the University of California Santa Cruz (UCSC) genome browser (http://genome.ucsc. edu/). PLINK (http://pngu.mgh.harvard.edu/purcell/plink/) was used for the statistical analysis of the data.

\section{Results}

The analysis of the sequences did not evidence new mutations with a functional effect on the development of disease. However, as regards the three polymorphisms selected, the comparison of the allelic frequencies in $\mathrm{CH}$ patients and in healthy smokers, highlighted a slight but statistically significant with regards to the SNP rs578776 localized on 3'-untranslated region (3'-UTR). The A allele, protective in the risk of developing nicotine addiction and obtained by the replacement of the aspartic acid with asparagine in position 398 , is less expressed $(p=0.038)$ in $\mathrm{CH}$ patients.

\section{Discussion}

$\mathrm{CH}$ patients seem to have a stronger genetic predisposition to develop smoke dependence. Probably, the excessive intake of nicotine could be associated with an up-regulation of pineal nicotinic receptor $\alpha 3 \beta 4$ [4], and this could trigger a dysfunction of melatonin release linked to the CH's chrono-biological profile.

Written informed consent to publication was obtained from the patient(s). 


\section{Authors' details}

${ }^{1}$ Headache and Drug Abuse Inter-Department Research Centre, University of Modena and Reggio Emilia, Modena, Italy. ${ }^{2}$ Department of Pharmacy and Biotechnology, University of Bologna, Bologna, Italy. ${ }^{3}$ Department of Biomedical, Metabolic and Neural Sciences, University of Modena and Reggio Emilia, Modena, Italy.

Published: 28 September 2015

\section{References}

1. Rozen TD: A history of cigarette smoking is associated with the development of cranial autonomic symptoms with migraine headaches. Headache 2011, 51:85-91.

2. Breetvelt EJ, Numans Me, Aukes MF, et al: The association of the alpha5subunit of the nicotinic acetylcholine receptor gene and the brainderived neurotrophic factor gene with different aspects of smoking behaviour. Psychiatr Genet 2012, 22:96-98.

3. Janes AC, Smoller JW, David SP, et al: Association between CHRNA5 genetic variation and rs 16969968 and brain reactivity to smoking images in nicotine dependent women. Drug Alcohol Depend 2012, 120:7-13.

4. Hernandez SC, Vicini S, Xiao Y, et al: The nicotinic receptor in the rat pineal gland is an a3ß34 subtype. Mol Pharmacol 2004, 66:978-987.

doi:10.1186/1129-2377-16-S1-A88

Cite this article as: Cainazzo et al:: O015. Evaluation of the genetic polymorphism of the $\alpha 3$ (CHRNA3) and $\alpha 5$ (CHRNA5) nicotinic receptor subunits, in patients with cluster headache. The Journal of Headache and Pain 2015 16(Suppl 1):A88.

\section{Submit your manuscript to a SpringerOpen ${ }^{\odot}$ journal and benefit from:}

- Convenient online submission

- Rigorous peer review

- Immediate publication on acceptance

- Open access: articles freely available online

- High visibility within the field

- Retaining the copyright to your article 